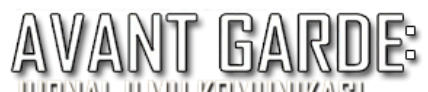

\title{
Strategi Komunikasi Pemerintah Kota Salatiga dalam Upaya Pencegahan Penyebaran COVID-19
}

\author{
Elisa Husein, Rini Darmastuti, Richard G. Mayopu \\ Universitas Kristen Satya Wacana. Indonesia. \\ huseinelisa@gmail.com
}

Submitted: 03 Agustus 2021, Revised: 08 September 2021, Accepted: 26 Oktober 2021

\begin{abstract}
Abstrak
Informasi tentang COVID-19 menjadi urgensi bagi setiap individu pada masa pandemi. Sayangnya tidak semua informasi disampaikan dengan strategi komunikasi yang tepat, sehingga menimbulkan dampak yang tidak diinginkan seperti ketakutan dan kemarahan. Pace, Paterson, dan Burnett mengatakan, strategi komunikasi memiliki tiga tujuan utama. Tulisan ini didasari oleh pendekatan kualitatif dan menggunakan analisis isi. Tulisan ini berusaha untuk menggali dan mendeskripsikan strategi komunikasi yang dilakukan oleh Pemerintah Kota Salatiga dalam upaya pencegahan penyebaran COVID-19 di Salatiga. Hasil dari tulisan ini adalah pertama, strategi komunikasi yang digunakan dalam menyampaikan informasi tentang COVID-19 adalah dengan menggunakan video, poster, dan lain-lain. Kedua, strategi komunikasi yang digunakan ini membawa dampak pada perubahan secara afektif, kognitif, dan perilaku. Ketiga, strategi komunikasi ini dapat dibuat dalam suatu model strategi komunikasi yang menekankan pada kredibilitas sumber, kejelasan isi serta media yang menarik. Berdasarkan hasil penelitian, dapat disimpulkan bahwa upaya-upaya yang telah dilakukan oleh Pemerintah Kota Salatiga dalam upaya untuk mencegah penyebaran COVID-19 di Salatiga belum membangun tingkat kesadaran yang penuh dari masyarakat, salah satunya disebabkan oleh kurang meratanya informasi yang disampaikan ke masyarakat Salatiga. Dengan begitu, strategi komunikasi Pemerintah Kota Salatiga masih dapat ditingkatkan lagi agar dapat menjadi suatu strategi komunikasi yang efektif.
\end{abstract}

Kata Kunci: Analisis isi; COVID-19; media sosial; pemerintah kota Salatiga; strategi komunikasi

\section{Salatiga City Government Communication Strategy for Preventing the Spread of COVID-19}

\begin{abstract}
Information about COVID-19 became an urgency for every individuals in this pandemic situation. Unfortunately, not all of the information were told in the appropriate communication strategy, it raised some unwanted impacts, such as fear and anger. Pace, Paterson, and Burnett, stated that communication strategy has three main purposes. This paper tried to dig up and describe the communication strategy of Salatiga City Government in their effort to prevent the spread of COVID-19 in Salatiga. The results are first, the informations about COVID-19 are delivered with video, poster, and others. Second, the strategy used gave impacts on changes in affective, cognitive and behavior. Third, this strategy could be made in a communication strategy model which emphasized in the source credibility, clarity of content, and interesting medias. The research revealed that this strategy hadn't built a full awareness of the society, one of the causes was the lack of even information delivered to the Salatiga society. Therefore, Salatiga City Government's communication strategy could be improved in order to be an effective communication strategy.
\end{abstract}

Keywords: Communication strategy; content analysis; COVID-19; Salatiga city government; social media 


\section{PENDAHULUAN}

Penyebaran COVID-19 di Indonesia sudah terjadi sejak bulan Maret tahun 2020 dan sudah menyebar ke banyak kota, termasuk Kota Salatiga di Jawa Tengah. COVID-19 sendiri merupakan penyakit menular yang disebabkan oleh jenis coronavirus yang baru ditemukan Berdasarkan WHO (World Health Organization), Coronavirus ini dikenal pertama kali saat terjadi wabah di Wuhan, Tiongkok, bulan Desember 2019 (WHO, 2020).

Dalam komunikasi pemerintahaan, terdapat dua tipe saluran komunikasi, yakni saluran komunikasi intern yang berkaitan dengan birokratik internal, fungsinya untuk memudahkan komunikasi di dalam internal publik pemerintahan dan saluran komunikasi ekternal, sebagai media komunikasi pemerintah dengan publiknya (Sriwartini, 2018). Beberapa upaya untuk mencegah penyebaran COVID-19 yang telah dilakukan oleh Pemerintah Kota Salatiga sebagai saluran komunikasi eksternal adalah dengan membuat update mengenai kasus COVID-19 di Salatiga dan mengedukasi masyarakat Salatiga untuk diam di rumah, mencuci tangan dengan sabun dan air mengalir, dan sebagainya melalui sebuah video. Hanya saja, tidak semua informasi ini disampaikan kepada masyarakat secara tepat. Ada beberapa informasi yang justru menimbulkan ketakutan bahkan kemarahan. Informasi yang dimaksud adalah informasi deskriptif yang menjelaskan bagaimana beberapa pasien COVID-19 terkena virus tersebut secara rinci. Hal ini bertentangan dengan pemahaman dasar dari suatu penyampaian informasi, dimana pada umumnya penyampaian informasi yang disampaikan oleh pemerintah seharusnya dapat mengedukasi masyarakat tanpa menimbulkan keresahan di tengah-tengah masyarakat.

Penyampaian informasi yang menimbulkan dampak yang tidak diinginkan adalah informasi mengenai kasus positif yang ketiga dan keempat yang dibuat dalam bentuk video. Di dalam video tersebut, Kepala Dinas Kesehatan Kota Salatiga Siti Zuraidah membagikan informasi mengenai bagaimana pasien kasus positif ketiga dan keempat yang mengidap COVID-19. Informasi yang disampaikan secara 'gamblang' dan rinci oleh kepala dinas kesehatan kota Salatiga ini ternyata justru menimbulkan kepanikan di masyarakat. Pada saat itu Ibu Zuraidah menjelaskan bahwa kedua kasus tersebut berhubungan. Dalam video yang berdurasi hampir 7 menit tersebut, Ibu Zuraidah menjelaskan bahwa kasus ketiga bersama suami dan anaknya ditelusuri pernah memiliki riwayat perjalanan ke berbagai manca negara, termasuk pada akhir bulan Februari. Anak dari kasus ketiga juga ditelusuri pernah mengunjungi Bali di bulan Maret dan anak dari kasus ketiga inilah yang menjadi kasus keempat. Selain riwayat perjalanan, dalam video tersebut juga dijelaskan riwayat kontak dan riwayat aktivitas yang dilakukan oleh kedua kasus tersebut. Ibu Zuraidah juga memberikan edukasi dan ajakan untuk melawan Corona kepada masyarakat di akhir video.

Di era keterbukaan informasi seperti sekarang ini, adanya transparansi atas berbagai kebijakan yang diambil pemerintah menjadi suatu kewajiban yang harus dilakukan (Fajri et al., 2018). Bukan hanya mengenai kebijakan yang diambil pemerintah, tapi juga informasi yang menyangkut kepentingan dan kebaikan masyarakat perlu dibagikan ke masyarakat. Maka dari itu, penyampaian informasi ini sangat berguna bagi masyarakat dan membuat masyarakat memahami apa yang terjadi. Di sisi yang lain, penyampaian informasi yang 
transparan ini ternyata justru menimbulkan dampak yang tidak diinginkan yang terjadi di masyarakat, yaitu adanya masyarakat yang justru menjadi panik, takut, bahkan marah dengan munculnya perilaku menyalahkan pasien-pasien tersebut. Selain itu, ada banyak masyarakat yang muncul perasaan ingin tahu siapa nama pasien-pasien ini bahkan sampai mencari tahu dimana rumahnya.

Reaksi masyarakat terhadap video tersebut dapat ditemukan di laman Facebook Humas Setda Salatiga serta pada bagian komen. Ada beberapa komen dari masyarakat yang menunjukkan amarah. Contohnya seperti komen yang ditulis oleh akun bernama Petra Petra Petra, yang bertuliskan:

"Mentang2 kaya....sombong, mau pamer ke tetangga kalo dari luar negeri akibatnya bawa oleh2 virus ke tetangga!!!! Ini juga perlu ditindak sekampung...knp kok masi ada pertemuan ibu2 PKK???? Padahal sdh jelas2 dilarang bergerombol!!!!!” (Facebook, 2020)

Reaksi masyarakat yang ditunjukkan pada komen di facebook hanya bagian kecil dari reaksi yang muncul di masyarakat terkait dengan kasus ini. Setelah melihat video tersebut, ada beberapa masyarakat yang menjadi ketakutan dan berusaha untuk menghindar dari tempat-tempat yang dikunjungi oleh pasien 3 dan 4 . Hal ini seperti yang dikatakan oleh pak Win, salah satu warga Salatiga yang mengatakan,

"Sebaiknya pada saat ini jangan lewat dekat pasar, karena pasien 3 dan 4 itu rumahnya dekat pasar. Ntar kalau kita lewat dekat rumah dia dan kita terkena virus yang ada di sekitar rumahnya bagaimana?"

Ketidaktahuan masyarakat terkait dengan COVID-19 secara tepat, seringkali membuat masyarakat memahami COVID-19 ini secara tidak tepat juga. Beberapa respon serta reaksi masyarakat yang muncul secara langsung maupun yang ditulis di media sosial merupakan respon yang tidak diinginkann. Penggunaan media sosial di dalam strategi komunikasi memang merupakan suatu langkah yang dapat berdampak kuat di masa sekarang. Contohnya seperti penelitian pesan strategi retorika dalam Facebook kampanye pemilihan gubernur yang ditulis oleh Sanjaya, Biyoga, dan Alunaza. Dalam penelitiannya, dinyatakan bahwa kampanye di Facebook mempunyai keunggulan dan kekuatan di dalam menggiring emosi dan keputusan audiens (Sanjaya et al., 2017). Dalam penelitian ini, respon dan reaksi yang salah satunya didapati dari media sosial juga dapat menjadi fenomena yang perlu dicermati, karena menimbulkan dampak yang tidak diinginkan. Oleh karena itu perlu dipikirkan strategi yang tepat dalam penyampaian informasi, terutama informasi yang sensitif di tengah pandemik ini.

Berdasarkan dari latar belakang ini, maka tulisan ini ingin bertujuan untuk menjelaskan mengenai strategi komunikasi Pemerintah Kota Salatiga dalam upaya mencegah penyebaran COVID-19 beserta dampaknya terhadap masyarakat Salatiga. Strategi komunikasi yang akan menjadi topik pembahasan di dalam tulisan ini adalah bagaimana pemerintah melakukan komunikasi eksternal yang efektif di masa pandemi. Strategi komunikasi yang dilakukan perlu efektif karena dengan strategi komunikasi yang tepat, komunitas dapat menggapai masyarakat dan informasi dapat tersampaikan dengan optimal (Grace et al., 2020). Informasi deskriptif yang membuat beberapa orang takut dan marah yang disampaikan Pemerintah Kota Salatiga ini dapat membantu untuk menemukan model 
strategi komunikasi eksternal efektif yang dapat dilakukan pemerintah pada masa pandemi. Hal tersebut juga menjadi tujuan lain dari tulisan ini. Tujuan ini dapat membantu individu, organisasi, atau bahkan pemerintah dalam membangun sebuah strategi komunikasi eksternal yang efektif.

\section{METODE PENELITIAN}

Tulisan ini didasarkan dari hasil penelitian deskriptif dengan pendekatan kualitatif. Menurut Erickson (1968, dalam Anggito \& Setiawan, 2018), penelitian kualitatif adalah penelitian yang berusaha untuk menemukan dan menggambarkan secara naratif kegiatan yang dilakukan dan dampak dari tindakan yang dilakukan terhadap kehidupan mereka. Selain itu tulisan ini juga menggunakan tipe desain penelitian studi kasus atau The Case Study. Yin (1989, dalam Remenyi, 2013) menyatakan bahwa a case study dapat dikatakan sebagai pertanyaan empiris yang meneliti fenomena yang sedang berjalan dengan melibatkan konteks kehidupan nyata, ketika batasan antara fenomena dengan konteks tidak terlalu terlihat, dan dimana beberapa sumber bukti digunakan. Tulisan ini diambil berdasarkan adanya suatu fenomena dan tulisan ini dilakukan untuk meneliti sebuah kasus tertentu yaitu model strategi komunikasi dari Pemerintah Kota Salatiga dalam melakukan upaya pencegahan penyebaran COVID-19 di Salatiga.

Penelitian ini dilakukan di Kota Salatiga, karena ada beberapa pesan-pesan edukasi kepada masyarakat yang dibuat Pemerintah Kota Salatiga yang justru menimbulkan dampak yang tidak diinginkan. Berdasarkan alasan itulah maka penelitian ini dilakukan di kota Salatiga. Narasumber dalam tulisan ini adalah humas atau staf humas dari Pemerintah Kota Salatiga yang merupakan pihak yang mendapatkan tanggung jawab untuk membuat strategi komunikasi di Pemerintah Kota Salatiga dalam masa pandemi ini. Selain itu, narasumber lainnya adalah masyarakat yang tinggal di kota Salatiga. Pengumpulan data ini dilakukan dari sekitar bulan April sampai sekitar bulan November 2020.

Teknik pengumpulan data yang digunakan dalam tulisan ini adalah wawancara, observasi, dan dokumentasi. Wawancara dalam tulisan ini dilakukan secara virtual. Observasi yang dilakukan dalam tulisan ini dilakukan secara langsung dan tidak langsung. Penulis menggunakan teknik dokumentasi dengan mencari dokumen yang berkaitan dan dapat mendukung tulisan ini secara online. Terdapat tiga hal yang dapat dilakukan agar dapat dikatakan sebagai perilaku analisis (Miles \& Huberman, 1994). Ketiga hal tersebut adalah reduksi data, penyajian data dan penggambaran kesimpulan atau verifikasi. Dengan begitu, tulisan ini juga menggunakan ketiga teknik analisis data tersebut.

\section{HASIL DAN PEMBAHASAN}

Berdasarkan hasil wawancara mendalam dengan PAW, Kepala Sub Bagian (Kasubag) Dokumentasi Pimpinan pada Bagian Protokol dan Komunikasi Pimpinan Sekretariat Daerah Kota Salatiga yang merupakan salah satu narasumber dalam tulisan ini, PAW menjelaskan strategi komunikasi yang digunakan sebagai strategi komunikasi Pemerintah Kota Salatiga dalam rangka pencegahan penyebaran COVID-19 di Salatiga pada awal-awal lebih banyak menggunakan media sosial. Upaya lainnya yang digunakan adalah dengan menggunakan 
baliho atau spanduk, videotron, pembuatan video publikasi, siaran radio siaran keliling, membuka nomor hotline, posko penanganan COVID-19, nomor telepon aduan, dan pembuatan stiker. Setelah pemerintah pusat mulai mengkampanyekan era adaptasi baru, PAW menyebutkan beberapa upaya yang masih digunakan dan ada juga yang baru ditambahkan. Diantaranya adalah menggunakan media sosial, media cetak (melalui rilis resmi), siaran radio, membuat baliho atau spanduk, membuat lomba video immunokompetensi, serta melakukan sosialisasi tatap muka secara terbatas.

Mengacu dari pendapat R. Wayne Pace, Brent D. Paterson, dan M. Dallas Burnett yang mengatakan bahwa strategi komunikasi memiliki tiga tujuan utama, yaitu to secure understanding, to establish acceptance dan to motivate action, strategi komunikasi yang dibuat oleh pemerintah kota Salatiga juga memiliki tujuan untuk membangun pemahaman, untuk melakukan pembinaan serta untuk memotivasi masyarakat. Berdasarkan pada 3 tujuan ini, maka informasi pemerintah yang disampaikan dengan menggunakan media poster disebarkan melalui media sosial dan website Pemerintah Kota Salatiga, dan video banyak disebarkan melalui media sosial. Strategi komunikasi yang dilakukan oleh pemerintah kota Salatiga ini dilakukan dengan menyesuaikan perkembangan teknologi informasi serta perubahan perilaku masyarakat dalam menggunakan media sebagai dampak dari pandemi. Hal ini dilakukan juga melihat kondisi masyarakat Indonesia yang pada saat ini berada pada fase transisi dimana ada perubahan dari kebiasaan masyarakat dalam mengakses dan mendistribusi informasi. Perubahan gaya hidup ini muncul karena adanya penggunaan alat komunikasi yang berbasis teknologi informasi atau ICT (Respati, 2014 dalam Kencana \& Meisyanti, 2020).

Di dalam pandemi COVID-19 ini, informasi yang benar serta cara penyampaian informasi yang tepat terkait dengan COVID-19 menjadi urgensi. Banyaknya informasi yang tersebar di masyarakat terkait dengan COVID-19 seringkali justru menimbulkan kebingungan masyarakat dan tidak jarang menimbulkan ketakutan, kekuatiran dan bahkan informasi yang menyesatkan. Kondisi ini sangat menyulitkan masyarakat ketika masyarakat akan menemukan informasi tentang COVID-19 dari sumber dan panduan yang dapat dipercaya. Yustitia dan Ashrianto (2020) dalam penelitiannya yang berjudul An Analysis on COVID-19 Disinformation Triangle in Indonesia mengatakan bahwa secara umum ada kecenderungan yang terjadi di masyarakat, yang pertama, Maret, April, dan Mei adalah bulan-bulannya dengan intensitas misinformasi dan disinformasi COVID-19 tertinggi selama Januari Juli. Kedua, Facebook, Twitter dan WhatsApp menjadi media yang paling sering digunakan untuk menyebar misinformasi tentang COVID-19 di Indonesia. Ketiga, ada tiga jenis misinformasi dan disinformasi tentang COVID-19 yang paling sering diproduksi dan didistribusikan yaitu konten menyesatkan, konten palsu, dan konteks palsu. Keempat, pendapat pribadi menjadi sumber misinformasi paling banyak tentang COVID-19 selama Januari-Juli 2020 (Yustitia \& Ashrianto, 2020).

Misinformasi dan disinformasi hanyalah dua dari sekian banyak penyebab munculnya kebingungan masyarakat akibat informasi terkait dengan COVID-19 yang tersebar di masyarakat. Hal lain yang dapat menimbulkan kebingungan, ketakutan dan kekuatiran akibat informasi COVID-19 adalah strategi penyampaian pesan yang tidak tepat. Strategi komunikasi yang tidak tepat, justru akan menimbulkan dampak yang tidak diinginkan. Hal ini 
pula yang pernah terjadi di Salatiga pada saat pemerintah kota Salatiga menyampaikan pesan atau informasi terkait dengan pasien COVID-19 ke 3 yang terjadi di Salatiga. Cara penyampaian pesan yang kurang tepat, ternyata justru menimbulkan ketakutan dan kemarahan beberapa masyarakat Salatiga. Efendy mengatakan strategi komunikasi pada hakikatnya adalah perencanaan (planning) dan manajemen (management) untuk mencapai tujuan (Effendy, 2005). Strategi komunikasi dalam pemahaman Middleton adalah kombinasi terbaik dari semua elemen komunikasi mulai dari komunikator, pesan, saluran (media) penerima sampai pada pengaruh (efek) yang dirancang untuk mencapai tujuan komunikasi yang optimal (Cangara, 2013).

Berdasarkan pengamatan yang dilakukan oleh penulis, berikut strategi komunikasi yang selama ini dilakukan oleh Pemerintah Kota Salatiga dalam upaya pencegahan penyebaran COVID-19 di Salatiga melalui video dan poster. Terkait dengan strategi komunikasi, Anwar Arifin (Arifin, 1984) mengatakan bahwa penyampaian pesan dapat dilihat dari 2 aspek, yaitu cara pelaksanaannya dan berdasarkan dari isi. Menurut cara pelaksanaannya metode komunikasi ini dapat diwujudkan dalam bentuk metode redundancy dan metode Canalizing. Metode redundancy merupakan cara mempengaruhi khalayak dengan jalan mengulang pesan kepada khalayak. Pesan yang diulang-ulang disampaikan kepada khalayak akan menjadi pesan yang menarik perhatian dan akan terekam dibenak khalayak. Metode Canalizing, merupakan metode dimana komunikator terlebih dahulu mengenal siapa khalayak sasarannya. Pengenalan kepada khayalak sasaran ini yang kemudian membuat komunikator dapat menyampaikan ide-denya sesuai dengan kepribadian, sikap dan motif khalayak.

Menurut bentuk isinya metode komunikasi diwujudkan dalam bentuk metode informatif, metode edukatif, metode Koersif dan Metode Persuasif. Metode Informatif merupakan metode yang bertujuan mempengaruhi khalayak dengan jalan memberikan penerangan. Penerangan berarti menyampaikan sesuatu apa adanya dan yang sesungguhnya terjadi. Metode Edukatif merupakan metode yang diwujudkan dalam bentuk pesan yang berisi pendapat, fakta dan pengalaman yang merupakan kebenaran dan dapat dipertanggungjawabkan. Penyampaian isi pesan disusun secara teratur dan berencana dengan tujuan mengubah perilaku khalayak. Metode Koersif merupakan metode untuk mempengaruhi khalayak dengan cara khalayak dipaksa untuk menerima gagasan atau ide. Metode Persuasif merupakan metode untuk mempengaruhi komunikan yang memposisikan mereka tidak terlalu banyak berpikir bahkan kadang-kadang khalayak dapat terpengaruh secara tidak sadar.

Selama ini, dalam menyampaikan pesan COVID-19, pemerintah kota Salatiga lebih banyak menggunakan metode komunikasi berdasarkan bentuk isinya. Hal ini bisa dilihat dari beberapa pendapat para narasumber di bawah ini. Salah satunya adalah respon positif dimana salah satu narasumber dari masyarakat yang bernama Ina mengatakan:

"Penyampaian informasinya positif sih, hanya kurang jelas saja, terlalu panjang juga. Mungkin pingin mengedukasi orang2 biar jaga jarak dan menghindari kerumunan (kumpul2 (kumpul-kumpul)), sama suruh jujur gitu ya," (wawancara 29 Juni 2020) 
Pendapat dari Ina tersebut dapat dihubungkan dengan isi dari video tersebut yang ditaruh di akhir video yaitu mengenai himbauan kepada masyarakat.

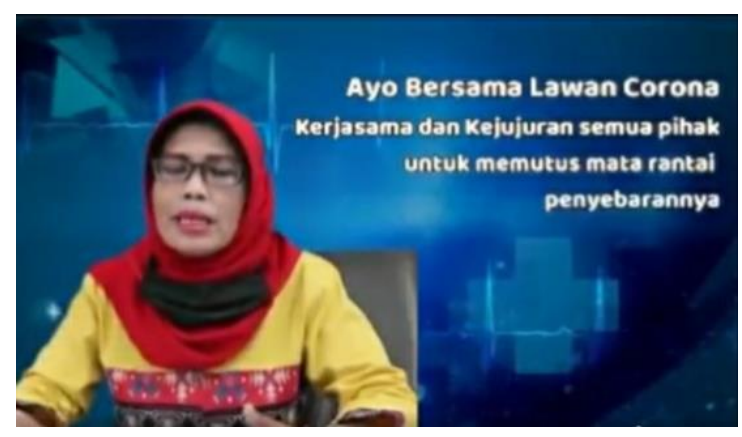

Gambar 1 Tangkapan Layar Video mengenai Himbauan kepada Masyarakat

Berdasarkan observasi yang telah dilakukan oleh penulis secara virtual melalui laman Facebook, ada beberapa pengguna Facebook yang meninggalkan komentar yang mengandung kebencian dan amarah kepada pasien yang disebutkan di dalam video. Para pengguna Facebook tersebut terlihat mendukung keterbukaan informasi yang diberikan di dalam video tersebut namun tidak mendukung tindakan dari kasus-kasus dalam video tersebut.

Keterbukaan informasi memang merupakan salah satu instrumen pencerdas bangsa yang merupakan refleksi dari keinginan dan kebutuhan masyarakat (Mustofa, 2020). Mustofa melanjutkan bahwa perkembangan kemajuan teknologi dan informasi yang begitu pesat memang menjadi tantangan tersendiri bagi pemerintah dalam mengelola informasi. Karena jika salah mengolah atau menyediakan informasi, maka keterbukaan informasi akan dapat menjadi "bumerang” bagi bangsa dan negara.

Berdasarkan respon dari beberapa narasumber masyarakat Salatiga yang telah diwawancarai oleh penulis, dapat diketahui bahwa informasi yang disampaikan dalam video tersebut mempunyai maksud dan isi yang positif namun penjelasan yang diberikan terlalu panjang dan dapat memunculkan reaksi yang beragam. Narasumber yang bernama Ina juga mengatakan bahwa penjelasan yang diberikan dalam video tersebut kurang jelas sehingga membuat penjelasannya menjadi membingungkan. Sedangkan menurut narasumber lain yang bernama Citra, video tersebut sudah efektif karena dapat mudah dipahami dan juga dapat disebarkan.

Menurut Lestari dan Maliki, terdapat lima aspek yang perlu dipahami dalam membangun komunikasi yang efektif. Pertama adalah kejelasan atau clarity, dimana bahasa maupun informasi yang disampaikan harus jelas. Kedua, ketepatan atau accuracy, artinya bahasa dan informasi yang disampaikan harus benar-benar akurat. Ketiga, konteks atau contex, artinya bahasa dan informasi yang disampaikan harus sesuai dengan keadaan dan lingkungan dimana komunikasi itu terjadi.

Selanjutnya alur atau flow, dimana keruntutan alur bahasa dan informasi akan sangat berarti dalam menjalin komunikasi yang efektif. Terakhir, budaya atau culture, poin ini menyangkut bahasa, informasi, tata krama, serta etika (Lestari dan Maliki (2006) dalam Cahyono, 2019). 
Maksud dari aspek kejelasan adalah bahwa dalam komunikasi harus menggunakan bahasa dan mengemas informasi secara jelas, sehingga mudah diterima dan dipahami oleh komunikan. Aspek lainnya yang disebutkan oleh Endang Lestari G adalah alur dan maksudnya adalah bahasa dan informasi yang akan disajikan harus disusun dengan alur atau sistematika yang jelas, sehingga pihak yang menerima informasi cepat tanggap. Berdasarkan kedua aspek yang dikemukakan oleh Endang Lestari G ini, video tersebut kurang memenuhi aspek kejelasan. Hal tersebut dikarenakan adanya narasumber yang mengatakan bahwa video tersebut mengandung kata-kata yang kurang dapat dipahami dan juga ada yang mengatakan bahwa video tersebut mengandung penjelasan yang membuatnya bingung. Narasumber lain juga ada yang memberikan masukan untuk menyertakan grafik atau tabel sehingga video tersebut tidak monoton.

Sedangkan jika diperhatikan dari aspek alur, video tersebut juga kurang memenuhi aspek ini dikarenakan durasi video yang dianggap narasumber terlalu panjang sehingga narasumber merasa malas untuk menonton video tersebut. Padahal video tersebut mempunyai isi pesan yang positif. Salah satu narasumber juga mengaku merasa kebingungan karena alur penyampaian informasi yang ada dalam video tersebut.

Berdasarkan wawancara yang dilakukan penulis terhadap beberapa masyarakat diketahui juga bahwa dari lima narasumber, empat diantaranya belum pernah menonton video tersebut. Dengan begitu dapat dikatakan bahwa penyebaran video tersebut masih perlu ditingkatkan lagi. Selain melalui video, upaya strategi komunikasi Pemerintah Kota Salatiga juga dituangkan dalam poster-poster yang disebarkan melalui media sosial dan website. Internet memang dapat mempermudah proses komunikasi dan pertukaran informasi di seluruh dunia (Alyusi, 2016). Melalui internet, masyarakat dapat dengan mudah mencari dan menemukan informasi yang diperlukan. Terutama dengan adanya keadaan pandemi seperti ini yang memaksa orang-orang untuk diam di rumah dalam upaya memutus rantai penyebaran COVID-19, orang-orang akan lebih cenderung mencari informasi di internet, salah satunya dapat melalui media sosial. Berikut contoh dari poster-poster yang dibuat oleh Pemerintah Kota Salatiga dalam upaya mencegah penyebaran COVID-19 di Salatiga.

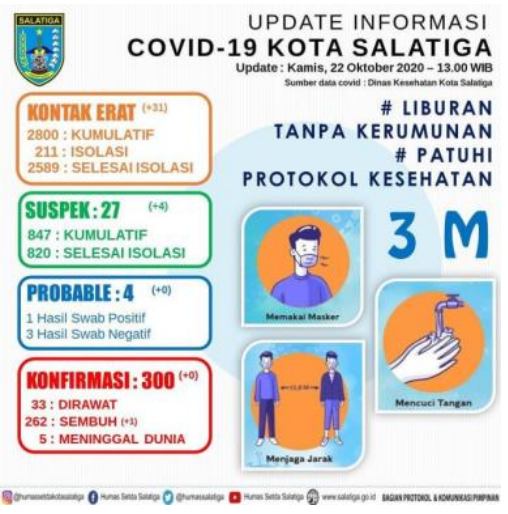

Gambar 2 Contoh Poster Update Informasi COVID-19 Kota Salatiga

Menurut narasumber PAW, strategi komunikasi berupa media maupun narasi komunikasi dipilih karena untuk menyesuaikan dengan kebijakan pemerintah pusat dalam upaya pencegahan penyebaran COVID-19. Strategi-strategi tersebut juga dipilih untuk 
menyamakan narasi tunggal antara pemerintah pusat dengan pemerintah daerah serta agar tidak menimbulkan kebingungan di tengah masyarakat dengan menyesuaikan kebutuhan masyarakat setempat.

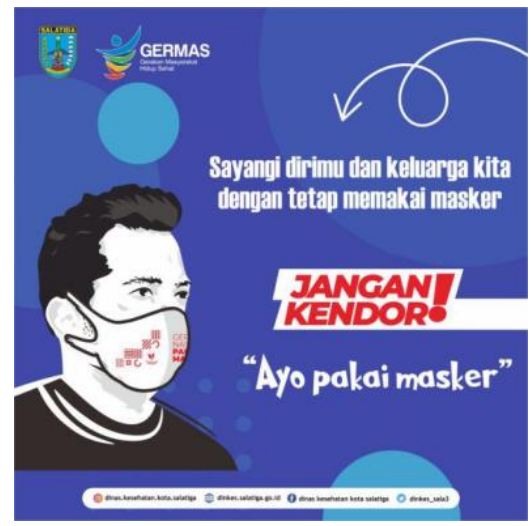

Gambar 3 Contoh Poster Himbauan

Setelah mengetahui upaya apa saja yang digunakan oleh Pemerintah Kota Salatiga dalam strategi komunikasi di saat masa pandemi, berikut dampak dari strategi komunikasi tersebut terhadap masyarakat Salatiga. Dalam bukunya yang berjudul Komunikasi Efektif di Masa Pandemi Covid-19: Pencegahan Penyebaran Covid-19 di Era 4.0 (KKN-DR), Ais menuliskan komunikasi dikatakan efektif apabila ia menghasilkan efek-efek atau perubahanperubahan seperti yang diharapkan oleh sumber, misalnya pengetahuan, sikap, dan perilaku, atau ketiganya (Ais, 2020).

Dampak dalam penelitian ini juga dibagi menjadi tiga, yaitu secara afektif, kognitif, dan perilaku. Tujuan komunikator bukan hanya sekadar supaya komunikan tahu, tetapi supaya hati dari komunikan juga tergerak dan agar menimbulkan perasaan tertentu kepada para komunikan, misalnya perasaan sedih, gembira, iba, dan sebagainya. Dengan begitu, dampak afektif memiliki kadar yang lebih tinggi dari dampak kognitif namun lebih rendah dari dampak terhadap perilaku atau behavioral (Kustini, 2017).

Dampak afektif yang muncul dari video ini terhadap masyarakat bermacam, diantaranya ada yang merasa marah, khawatir, bahkan ada yang merasa senang. Salah satu narasumber masyarakat yang mengaku merasa senang setelah menyaksikan video tersebut adalah Dea.

"Reaksi aku jadi agak khawatir sama seneng sih ci. Agak khawatir soalnya si virusnya itu gampang banget pindah dari satu orang ke orang lainnya. Di satu sisi seneng juga sih soalnya masih ada yang peduli terus mau ngingetin orang lain tentang pandemi” (wawancara 14 Oktober 2020)

Reaksi yang diutarakan oleh Dea tersebut merupakan suatu reaksi yang menarik karena berbeda dari reaksi pada umumnya. Sudut pandang yang digunakan oleh Dea berbeda dari sudut pandang yang digunakan oleh narasumber lainnya dan yang digunakan oleh para pengguna Facebook yang berkomentar di video tersebut. Kebanyakan dari para pengguna Facebook yang berkomentar tersebut mempunyai reaksi marah setelah menyaksikan video tersebut. Salah satu narasumber yang berhasil dimintai pendapat, Citra juga mengatakan bahwa reaksinya setelah menonton video tersebut adalah marah. 
"Marah dan khawatir el, marah karena yang positif ga menaati protokol kesehatan lalu jadi khawatir kalo ikut tertular" (wawancara 13 Oktober 2020)

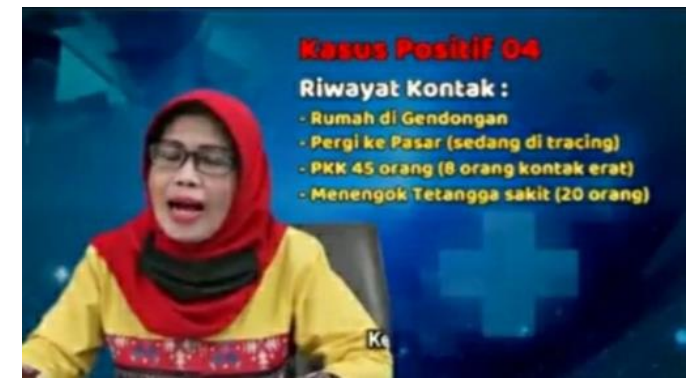

Gambar 4 Tangkapan Layar Video mengenai Riwayat Kontak Kasus Positif 04

Selain dari beberapa reaksi yang telah dijelaskan di atas, ada reaksi lainnya dari masyarakat yang berkesempatan menjadi narasumber dalam pengumpulan data ini. Reaksi tersebut adalah bingung dengan informasi yang diberikan dalam video tersebut serta malas untuk menyaksikan penyampaian dalam video tersebut karena durasi video yang menurutnya terlalu panjang.

Beberapa masyarakat mengatakan bahwa poster-poster yang ada dapat membuat orang-orang menjadi khawatir dan takut. Namun, dampak ini dapat menjadikan orang-orang menjadi waspada dan berjaga-jaga. Salah satu yang berpendapat seperti ini adalah narasumber yang bernama Ina. Ina mengatakan:

“... pling (paling) jdi (jadi) waswas pas baca yg (yang) peta sebaran positif covid, otg dan sembuh. Kaya ih ternyata dah sampai daerah cebongan,, ngeri dah klo (kalau) dah dekat dengan daerah tempat tinggal. Sama wah makin hari makin banyak, jdi (jadi) takut" (wawancara 20 November 2020)

Beberapa orang di media sosial juga ditemukan meninggalkan komentar yang menyatakan secara konotatif bahwa mereka merasa takut. Pendapat tersebut dapat mempunyai arti bahwa dampak dari strategi komunikasi melalui poster dapat membuat orang-orang menjadi sadar bahwa pandemi yang sedang dihadapi itu sangat berbahaya. Sehingga, para masyarakat dapat merubah perilakunya agar tidak ikut tertular virus ini.

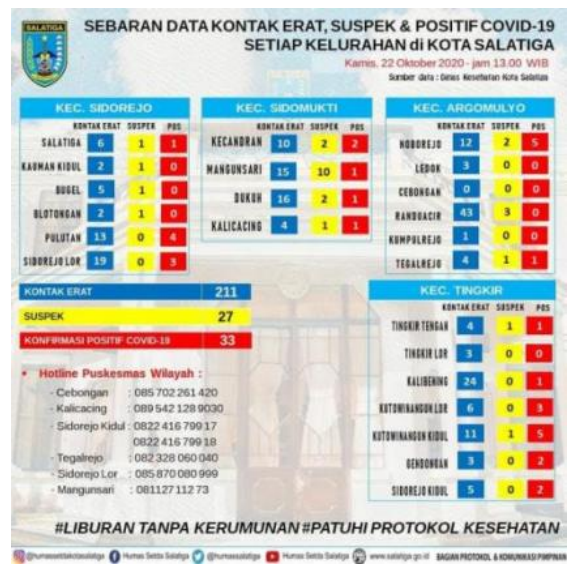

Gambar 5 Contoh Poster yang Berisi Jumlah Data COVID-19 di Salatiga 
Dampak kognitif adalah dampak yang timbul pada komunikan yang menyebabkan komunikan menjadi tahu atau meningkatkan intelektualitas dari komunikan. Dalam dampak ini, tujuan komunikator adalah berupaya untuk mengubah pikiran dari komunikan (Kustini, 2017). Berdasarkan observasi yang dilakukan oleh penulis, didapatkan bahwa keadaan Kota Salatiga tidak terlalu berbeda jauh dibandingkan sebelum pandemi COVID-19 terjadi. Hal ini menunjukkan bahwa strategi komunikasi yang digunakan belum terlalu berdampak terhadap kognitif dari masyarakat Salatiga. Pasar tradisional tetap dalam keadaan dan kondisi ramai akan pengunjung, hanya perbedaannya adalah kebanyakan pengunjung pasar menggunakan masker. Tapi terkadang masyarakat juga tidak menggunakan masker dengan benar. Hal ini juga disampaikan oleh salah seorang narasumber yang diwawancara oleh penulis, yaitu $\mathrm{F}$ yang mengatakan:

“... klo (kalau) protokolnya sih yg (yang) sering aku liat kadang pake
masker ya pake cmn (cuman) makeknya nggk (ga) bnr (bener) dan bbrp
(beberapa) aku sempet nanya jg (juga) bbrp (beberapa) org (orang) tua
gtu (gitu) kan yg (yang) dijalan alasanya emg (emang) nggk (ga)
terbiasa jdi (jadi) susah nafas jd (jadi) makenya hidung nya nggk (ga)
ketutup ,...” (wawancara 13 Oktober 2020)

Kebiasaan berjabat tangan ketika bertemu dengan orang lain juga merupakan suatu perilaku yang menunjukkan dampak terhadap perilaku masyarakat Salatiga tidak terlalu terasa. Hal ini juga menunjukkan kurangnya dampak positif terhadap kognitif dari masyarakat. Bahkan menurut narasumber yang bernama Ina, masih ada yang sering menggelar suatu perayaan yang dihadiri oleh banyak orang.

Selain itu berdasarkan observasi penulis, beberapa tempat umum sudah memberlakukan protokol physical distancing dan protokol kesehatan lainnya, seperti menyediakan tempat cuci tangan beserta sabun. Mengenai hal ini, ada juga narasumber yang mempunyai pendapat yang sama tapi menurutnya kapasitas tempat makan masih penuh dan tidak terlalu memberlakukan protokol physical distancing. Tapi menurut Citra, di tempat umum sudah menerapkan peraturan jaga jarak dengan memberikan tanda pada kursi. Perbedaan pendapat ini dapat didasarkan kepada waktu para narasumber mengunjungi tempat umum dan perbedaan tempat umum yang dimaksud oleh pada narasumber.

Namun jika ditinjau dari poster, dampak terhadap kognitif kepada masyarakat cukup terasa. Hal tersebut dapat disebabkan karena isi pesan dari poster itu sendiri merupakan himbauan dan merupakan jumlah data COVID-19 yang dapat menambah pengetahuan dari para pembaca. Isi dari poster juga mungkin dapat dipahami dengan mudah oleh masyarakat. Selain menambah pengetahuan dan wawasan kepada para pembaca, dampak lain terhadap kognitif dari para masyarakat adalah isi dari poster tersebut dapat menjadi pengingat atau reminder. Hal tersebut dikatakan oleh salah satu narasumber yang bernama ADK:

"Eh itu ya dampaknya ya ngasih awasan, jadi kayak reminder juga sih. Reminder kalau harus mentaati protokol, jaga kesehatan juga lewat protokol itu kaya gitu." (wawancara 20 November 2020)

Berdasarkan observasi penulis melalui media sosial, melalui poster-poster yang dipublikasikan tersebut, beberapa orang melalui komentarnya menyatakan bahwa mereka sadar untuk disiplin menerapkan protokol kesehatan. Selain itu, beberapa orang menjadi 
mengetahui perkembangan jumlah data COVID-19 per daerah di Salatiga. Contohnya adalah komentar yang ditulis oleh ikanugroho77 di Instagram yang menuliskan:

"penambahan pasien positif 53 orang dalam sehari"

Ketika penulis menanyakan kepada PAW dampak apa yang dihasilkan dari strategi komunikasi Pemerintah Kota Salatiga, beliau menjawab:

"Berbagai publikasi yang telah dilakukan secara continue telah meningkatkan pengetahuan dari masyarakat mengenai bahaya covid, dan bagaimana menghindarinya." (wawancara 17 November 2020)

Dengan begitu pendapat-pendapat narasumber di atas dapat diketahui sesuai dengan jawaban dari pihak Pemerintah Kota Salatiga. Dimana hal tersebut dapat menunjukkan bahwa tujuan strategi komunikasi yang melalui poster telah tercapai, yaitu meningkatkan pengetahuan masyarakat tentang bahaya COVID-19 dan mengedukasi masyarakat mengenai cara untuk menghindari COVID-19.

Pengaruh terhadap perilaku masyarakat Salatiga diukur dari pendapat para narasumber mengenai sikap dan perilaku masyarakat Salatiga walaupun telah diberikan peringatan oleh Pemerintah Kota Salatiga, salah satunya melalui video yang dibahas dalam tulisan ini. Salah satu narasumber yang bernama Citra menyatakan bahwa tingkat kesadaran masyarakat Salatiga akan COVID-19 ini mulai berkurang dibandingkan bulan-bulan sebelumnya. Citra mengatakan:

"Tingkat kesadaran sekarang ni mulai berkurang dari pada bulan2 (bulan-bulan) lalu, sekarang tempat nongkrong tetep penuh dan pada gak pake masker el, jadi masi harus diingatkan.." (wawancara 13 Oktober 2020)

Sedangkan informasi yang terdapat dalam poster memiliki visualisasi yang lebih menarik sehingga dapat lebih mudah dicerna. Menurut Sachari, nilai-nilai estetik modern di Indonesia dalam memantapkan kebudayaan benda memiliki tiga makna utama, yaitu sebagai pendukung proses penyadaran, sebagai penyumbang pembelajaran kepada masyarakat, dan sebagai unsur pembudayaan budaya visual (Sachari, 2007). Dua di antara tiga makna tersebut menyatakan bahwa visualisasi dapat mendukung proses penyadaran dan dapat memberikan pembelajaran kepada masyarakat.

Menurut PAW sebagai salah satu narasumber dari tulisan ini yang mewakili Pemerintah Kota Salatiga, masyarakat mulai membiasakan diri dengan mengikuti protokol kesehatan dalam adaptasi kebiasaan baru masyarakat yang tetap produktif dan aman meskipun berada di tengah pandemi COVID-19 ini. Berikut pernyataan dari pihak PAW:

"Dan masyarakat secara individu maupun bersama-sama mulai membiasakan diri melaksanakan protokol kesehatan dalam pelaksanaan era adaptasi kebiasaan baru masyarakat yang produktif dan aman Covid-19." (wawancara 17 November 2020)

Salah satu narasumber yang bernama Citra menyatakan hal yang mendukung pernyataan dari pihak Pemerintah Kota Salatiga tersebut, dengan mengatakan:

"Berubah el, karena klo (kalau) habis baca jadi mikir buat ttep (tetap) jaga jarak sama pake masker, soalnya aku parnoan.." (wawancara 20 November 2020)

Namun meskipun ada sebagian masyarakat Salatiga yang sudah mulai membiasakan diri dalam adaptasi yang baru itu, masih ada juga masyarakat Salatiga yang tidak 
mempedulikan protokol kesehatan yang ada atau himbauan yang tertera dalam poster yang sudah disebarkan tersebut. Hal ini didukung dengan pernyataan dari salah satu narasumber yang bernama Dea.

"Menurut aku kayaknya sebagian besar udah nerapin prokes, kaya pake masker, cuci tangan, jaga jarak. Tapi tetep ada yang nggak peduli sama prokes" (wawancara 20 November 2020)

Penulis juga menemukan adanya komentar yang ditulis akun bernama widhi_wismanti dalam media sosial Instagram yang mengatakan:

“@humassetdakotasalatiga.. kesadaran masyarakat memang knci penting, tapi kami juga membutuhkan bantuan dr pemerintah kota untuk menertibkan kembali kegiatan pengumpulan massa seperti acara pernikahan dll, krn byk sekali yg masih berencana mengadakan kegiatan spt ini dan mengundang byk orang sehingga meresahkan yang disekiarnya. Mohon bantuannya"

Dengan pernyataan itu, dapat diketahui masih adanya masyarakat yang belum merubah kebiasaanya dan masih lalai dalam mematuhi protokol kesehatan. Meskipun begitu, ada juga dampak positif yang dihasilkan dari poster terhadap perilaku masyarakat Salatiga, yaitu adanya sikap kepedulian dengan cara menegur orang yang tidak memakai masker.

Dalam jurnalnya, Buluamang menemukan hasil penelitian yang berupa pengetahuan bahwa suatu tindakan komunikasi yang ditunjukkan oleh kepala daerah di hadapan publik mendapat pengamatan dari publik karena hubungan antara perilaku komunikasi dengan citra publik begitu kuat. Kuatnya hubungan tersebut disebabkan oleh kuatnya hubungan kompetensi komunikasi, keterampilan komunikasi dan konsistensi komunikasi dengan citra publik (Buluamang, 2018).

Hendrix dan Hayes juga mengatakan (2007 dalam Korniawan, 2019) terdapat sembilan indikator terkait mengenai bagaimana membangun komunikasi yang efektif. Kesembilan indikator yang tercatat dalam buku Kreativitas Komunikasi Bagi GPR di dalam Komunikasi Krisis adalah sebagai berikut. Pertama adalah terpenuhinya kredibilitas dari sumber informasi yang diperoleh. Indikator yang kedua adalah tersedianya informasi yang jelas. Ketiga, tersedianya petunjuk verbal yang efektif. Indikator selanjutnya adalah tersedianya petunjuk nonverbal yang efektif. Kelima, terciptanya komunikasi dua arah. Keenam, terbangunnya opinion leaders. Selanjutnya, terbangunnya pengaruh dari kelompok yang ada. Indikator kedelapan adalah terbangunnya pemaparan atau penjelasan yang selektif. Terakhir, terbangunnya partisipasi audiens.

Berdasarkan sembilan indikator yang telah dituliskan di atas, ada beberapa indikator yang berhubungan dengan strategi komunikasi pemerintah. Pertama, informasi yang disediakan atau disampaikan mempunyai kredibilitas yang tinggi dan berasal dari sumber informasi yang terpercaya. Terutama jika penyampai informasi adalah suatu institusi yang perlu dipercaya oleh banyak orang, misalnya pemerintah yang perlu dipercaya oleh masyarakat. Karena jika tidak demikian, jika informasi yang disampaikan salah dapat memunculkan suatu keributan atau kericuhan dan kepercayaan masyarakat terhadap pemerintah dapat berkurang bahkan dapat menjadi hilang. Hal ini dapat berdampak terhadap kemajuan dan kesatuan negara itu sendiri. 
Informasi yang disampaikan dari pihak mana pun jika ingin berlangsung secara efektif, memang perlu tersampaikan dengan jelas, baik dari cara penyampaiannya maupun dari isi informasi. Pemerintah Kota Salatiga juga perlu menyampaikan informasi dengan efektif dalam upaya mencegah penyebaran COVID-19 ini. Selain itu, pemerintah juga perlu menyampaikan informasi secara terbuka agar masyarakat dapat percaya kepada pemerintah. Penyampaian informasi secara efektif ini dilakukan agar tidak menimbulkan perbedaan isi pesan yang disampaikan oleh pemerintah dengan apa yang ditangkap oleh masyarakat atau dengan kata lain agar tidak menimbulkan kesalahpahaman antara pemerintah dengan masyarakat, contohnya untuk mencegah sikap amarah atau keresahan masyarakat yang disebabkan oleh apa yang disampaikan di dalam video dari Pemerintah Kota Salatiga.

Jika diperhatikan dari salah satu pendapat narasumber yang meyatakan bahwa beliau tidak menonton video dari Pemerintah Kota Salatiga secara lengkap karena durasinya yang panjang, maka dapat dikatakan pemerintah perlu menyampaikan informasi dengan cara yang dapat membuat audiens tertarik untuk menyimak isi informasi dengan baik dan seksama agar dapat mempengaruhi masyarakat baik secara afektif, kognitif, maupun secara perilaku. Pemerintah juga perlu membuat audiens dapat merasa yakin dan percaya kepada apa yang disampaikan oleh pemerintah. Misalnya, menentukan siapa komunikatornya, bagaimana cara penyampaian informasi yang dilakukan oleh komunikator, media apa yang digunakan, berapa lama penyampaian informasi tersebut dilakukan, dan sebagainya. Jika muncul permasalahan, pemerintah bisa menggunaka model komunikasi two-way symmetrical, dimana model komunikasi tersebut memfokuskan penggunaan komunikasi untuk mengatur konflik dan memperbaki persepsi publik secara metodis (Saidah \& Rusfian, 2020).

Setelah tersampaikan kepada masyarakat, tanda bahwa strategi komunikasi yang digunakan efektif adalah dengan adanya partisipasi dari masyarakat itu sendiri. Hal ini menunjukkan bahwa informasi yang disampaikan dapat dipahami dan memberikan perubahan yang baik di dalam diri masyarakat. Dampak dapat berupa dampak terhadap sisi afektif, kognitif, dan perilaku dari masyarakat. Selain itu, hal tersebut juga akan membuktikan bahwa informasi yang diberikan telah tersampaikan ke seluruh masyarakat yang dituju dengan merata. Misalnya, masyarakat menjadi tahu daerah mana saja yang sedang zona merah, sadar untuk patuh pada protokol kesehatan, dan menjauhi keramaian. Dengan demikian tujuan dari penyampaian informasi dapat tercapai.

Berikut bagan yang menjabarkan konsep atau model strategi komunikasi yang dapat digunakan dalam pemerintahan.

Bagan 1 Konsep Strategi Komunikasi Pemerintah

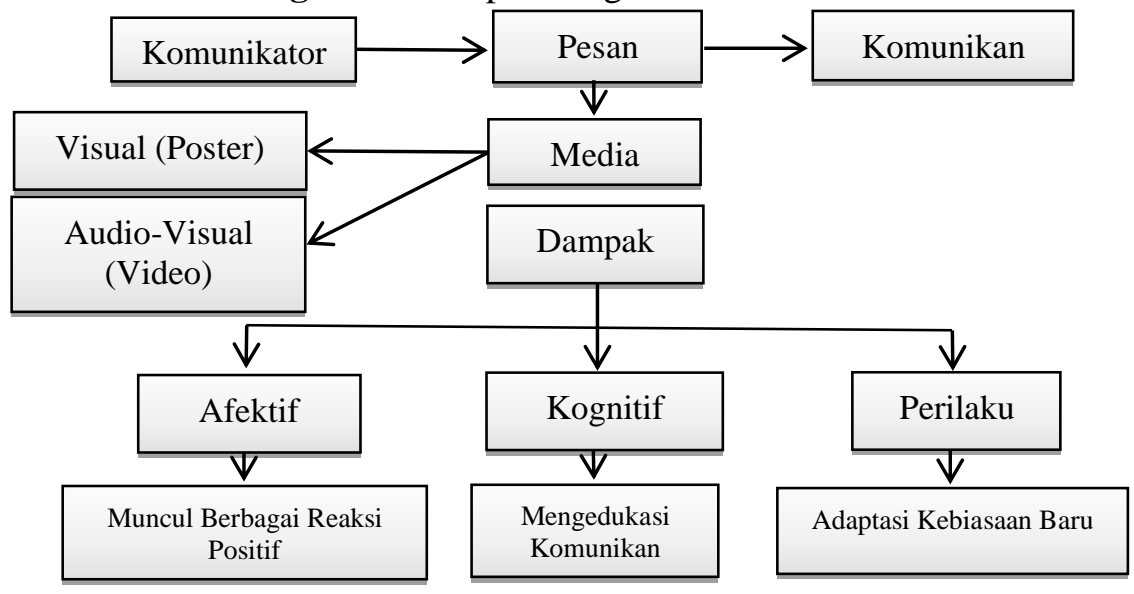




\section{SIMPULAN}

Berdasarkan hasil penelitian, dapat disimpulkan bahwa upaya-upaya yang telah dilakukan oleh Pemerintah Kota Salatiga dalam upaya untuk mencegah penyebaran COVID19 di Salatiga mempunyai banyak macam upaya, namun dalam tulisan ini penulis memfokuskan penelitian terhadap dua media, yaitu melalui video penjelasan kasus COVID19 dan melalui poster-poster informasi seputar COVID-19 serta poster-poster yang berisikan himbauan yang disebarkan melalui website dan media sosial.

Informasi penjelasan kasus COVID-19 dalam video mengandung beberapa informasi yang menyebabkan kontroversial di tengah-tengah masyarakat. Penulis berpendapat video dapat dibuat dengan durasi yang tidak terlalu panjang dan sebaiknya berisikan pesan update terkini mengenai kasus COVID-19 di Salatiga serta himbauan-himbauan yang dibungkus dengan singkat, padat, dan jelas. Video juga dapat disebarkan secara lebih meluas sehingga dapat menjangkau seluruh masyarakat Salatiga.

Upaya melalui poster-poster yang penulis temukan dari media sosial maupun dari website Pemerintah Kota Salatiga dapat terus digunakan sebagai pengingat kesadaran dan pengedukasi masyarakat Salatiga akan COVID-19.

Upaya-upaya yang dilakukan tersebut telah memberikan dampak baik secara afektif, kognitif, maupun terhadap perubahan perilaku dari masyarakat Salatiga. Hanya saja dampak tersebut tidak berdampak merata ke seluruh masyarakat Salatiga, yang mungkin dapat disebabkan oleh kesadaran masyarakat Salatiga sendiri yang masih kurang serta sikap masyarakat yang masih acuh tak acuh atau tidak peduli. Selain itu juga dapat dikarenakan informasi yang disampaikan tidak tersebar secara merata ke seluruh masyarakat Salatiga.

Strategi komunikasi pemerintah yang efektif dalam upaya pencegahan penyebaran suatu penyakit adalah diawali dengan isi dari informasi yang ingin disampaikan ke masyarakat. Isi tersebut harus merupakan suatu informasi yang kredibel, jelas, serta penting untuk disebarkan ke masyarakat. Setelah itu, pemilihan media sebagai tempat informasi disampaikan juga harus tepat sasaran. Cara penyampaian, atribut yang digunakan dalam penyampaian informasi dan sebagainya juga perlu direncanakan dengan matang. Dengan begitu, informasi dapat sampai ke masyarakat dengan mudah dan cepat sehingga dapat dipahami serta dijalankan oleh masyarakat.

Setelah informasi yang ingin disampaikan diterima oleh masyarakat, keefektifan strategi komunikasi yang digunakan dapat diketahui dari dampak yang dihasilkan. Dampakdampak tersebut diharapkan dapat sesuai dengan harapan dan tujuan yang telah ditentukan oleh pemerintah. Setelah terbukti efektif, pemerintah dapat menggunakan stategi komunikasi tersebut lagi di saat diperlukan.

\section{UCAPAN TERIMA KASIH}

Penulis mengucapkan syukur dan terima kasih pertama-tama ke pada Tuhan Yesus atas bantuan dan penyertaan-Nya selama penulis menyusun artikel ini. Penulis juga mengucapkan terima kasih kepada Universitas Kristen Satya Wacana, para dosen yang telah membimbing, keluarga yang mendukung, serta teman-teman yang ikut menyemangati. Terima kasih saya ucapkan juga ke pada seluruh pihak Jurnal Avant Garde yang telah memberikan kesempatan 
ke pada saya untuk menyajikan artikel ini, dan kepada reviewer yang telah memberikan masukan untuk memperbaiki artikel ini.

\section{DAFTAR PUSTAKA}

Ais, R. (2020). Komunikasi Efektif di Masa Pandemi Covid-19: Pencegahan Penyebaran Covid-19 di Era 4.0 (KKN-DR). Makmood Publishing.

Alyusi, S. D. (2016). Media Sosial: Interaksi, Identitas dan Modal Sosial (Pertama). Kencana.

Anggito, A., \& Setiawan, J. (2018). Metode Penelitian Kualitatif. CV Jejak.

Arifin, A. (1984). Strategi Komunikasi Suatu Pengantar Ringkas. Armico.

Buluamang, Y. M. O. (2018). Hubungan Antara Perilaku Komunikasi Kepala Daerah Dengan Citra Publik dan Ekspektasi Publik. Jurnal Studi Komunikasi Dan Media.

Cahyono, A. (2019). Menciptakan Sebuah Kekuatan Komunikasi Efektif: Unggul Berkomunikasi. Uwais Inspirasi Indonesia.

Cangara, H. (2013). Perencanaan Strategi Komunikasi. PT RajaGrafindo Persada.

Effendy, O. U. (2005). Ilmu Komunikasi Teori dan Praktek. Remaja Rosda Karya.

Effendy, O. U. (2013). Ilmu Komunikasi Teori dan Praktek. PT Remaja Rosdakarya.Facebook. (2020). No Title. https://www.facebook.com/humas.joss/videos/921127488325936/?_so__=channel_t ab\&_rv__=all_videos_card

Fajri, C., Mawadati, S., \& Yudhana, A. (2018). Komunikasi Sosial Pemerintah Kulon Progo Dalam Memberikan Pemahaman Kepada Masyarakat Terkait Pembangunan New Yogyakarta Internasional Airport. Komunikator, 10(2). https://doi.org/10.18196/jkm.101012

Grace, S., Tandra, A., \& Mary. (2020). Komunikasi Efektif dalam Meningkatkan Literasi Kesehatan Mental. Jurnal Komunikasi, 12(2).

Kencana, W. H., \& Meisyanti, M. (2020). The Implementation of Mass Media Digital Platform in Indonesia. Komunikator, 12(2). https://doi.org/10.18196/jkm.122038

Korniawan, R. (2019). Kreativitas Komunikasi Bagi GPR di dalam Komunikasi Krisis. Uwais Inspirasi Indonesia.

Kustini, H. (2017). Communication Skill. Penerbit Deepublish.

Miles, M. B., \& Huberman, A. M. (1994). Qualitative Data Analysis: An Expanded Sourcebook (Second). SAGE Publications, Inc.

Mustofa, S. (2020). Hukum Keterbukaan Informasi Publik di Indonesia. Guepedia.

Remenyi, D. (2013). Case Study Research: The Quick Guide Series: 2nd Edition (Kedua). : Academic Conferences and Publishing International Limited.

Sachari, A. (2007). Budaya Visual Indonesia: Membaca Makna Perkembangan Gaya Visual Karya Desain di Indonesia abad ke-20. Penerbit Erlangga.

Saidah, M., \& Rusfian, E. Z. (2020). Hoax management of presidential staff office: An example of government public relations strategies. Jurnal Studi Komunikasi (Indonesian Journal of Communications Studies), 4(1), 32. https://doi.org/10.25139/jsk.v4i1.1769

Salatiga, P. K. (2020). Salatiga Tanggap COVID-19. https://corona.salatiga.go.id/ 
Sanjaya, A., Biyoga, S., \& Alunaza, H. (2017). Pemimpin Minoritas dan Strategi Retorika Pathos dalam Kampanye: Analisis Isi Deskriptif Pesan Strategi Retorika dalam Facebook Kampanye Pemilihan Gubernur. Jurnal Komunikasi Indonesia, VI(2).

Sriwartini, Y. (2018). Manajemen Komunikasi Pemerintah Desa dalam Melaksanakan Forum Keamanan Terpadu (Kajian Pada Kelurahan Balekambang Jakarta Timur). Ekspresi Dan Persepsi: Jurnal Ilmu Komunikasi, 1(01), 17-32. https://doi.org/10.33822/jep.v1i01.438

WHO. (n.d.). Pertanyaan dan jawaban terkait Coronavirus. Retrieved April 24, 2020, from https://www.who.int/indonesia/news/novel-coronavirus/qa-for-public

Yustitia, S., \& Ashrianto, P. D. (2020). An Analysis on COVID-19 Disinformation Triangle in Indonesia. Jurnal Komunikator, 12(2), 125. 